\title{
Erratum to: Response variation across a strong rainfall gradient in two naturalized annual grass species
}

\author{
Andrew R. Dyer • Shana J. Woodward • \\ Jeffery E. Petersen
}

Published online: 29 April 2016

(C) Springer Science+Business Media Dordrecht 2016

\section{Erratum to: Plant Ecol \\ DOI 10.1007/s11258-016-0590-0}

Unfortunately in the original publication of the article, one of the author's name was incorrectly published. However the correct name is included in this erratum.

Communicated by Prof. Lauchlan Fraser, Dr. Chris Lortie, Dr. JC Cahill.

The online version of the original article can be found under doi: 10.1007/s11258-016-0590-0.

A. R. Dyer $(\bowtie) \cdot$ S. J. Woodward · J. E. Petersen Department of Biology and Geology, University of South Carolina Aiken, 471 University Parkway, Aiken, SC, USA

e-mail: andyd@usca.edu 